\title{
The intensity of slope and fluvial processes after a catastrophic windthrow event in small catchments in the Tatra Mountains
}

\author{
Dariusz STRZYŻOWSKI* (iD https://orcid.org/oooo-00o2-6271-3028; \e-mail: dariusz.strzyzowski@doctoral.uj.edu.pl \\ Elżbieta GORCZYCA iD https://orcid.org/oooo-0oo1-8348-4132; e-mail: elzbieta.gorczyca@uj.edu.pl \\ Kazimierz KRZEMIEŃ ID https://orcid.org/oooo-0002-9417-1243; e-mail: kazimierz.krzemien@uj.edu.pl \\ Mirosław ŻELAZNY iD https://orcid.org/oooo-0oo2-9022-1039; e-mail: miroslaw.zelazny@uj.edu.pl \\ ${ }^{*}$ Corresponding author \\ Institute of Geography and Spatial Management, Jagiellonian University, Gronostajowa 7, Kraków 30-387, Poland
}

Citation: Strzyżowski D, Gorczyca E, Krzemień K, et al. (2021) The intensity of slope and fluvial processes after a catastrophic windthrow event in small catchments in the Tatra Mountains. Journal of Mountain Science 18(6). https://doi.org/10.1007/s11629-021-6726-2

(C) The Author(s) 2021.

\begin{abstract}
Strong wind events frequently result in creating large areas of windthrow, which causes abrupt environmental changes. Bare soil surfaces within pits and root plates potentially expose soil to erosion. Absence of forest may alter the dynamics of water circulation. In this study we attempt to answer the question of whether extensive windthrows influence the magnitude of geomorphic processes in 6 small second- to third-order catchments with area ranging from $0.09 \mathrm{~km}^{2}$ to $0.8 \mathrm{~km}^{2}$. Three of the catchments were significantly affected by a windthrow which occurred in December 2013 in the Polish part of the Tatra Mountains, and the other three catchments were mostly forested and served as control catchments. We mapped the pits created by the windthrow and the linear scars created by salvage logging operations in search of any signs of erosion within them. We also mapped all post-windthrow landslides created in the windthrow-affected catchments. The impact of the windthrow on the fluvial system was investigated by measuring a set of channel characteristics and determining bedload transport intensity using painted tracers in all the
\end{abstract}

Received: 03-Feb-2021

Revised: 08-Apr-2021

Accepted: 19-May-2021 windthrow-affected and control catchments. Both pits and linear scars created by harvesting tend to become overgrown by vegetation in the first several years after the windthrow. The only signs of erosion were observed in $10 \%$ of the pits located on convergent slopes. During the period from the windthrow event in 2013 until 2019, 5 very small (total area $<100 \mathrm{~m}^{2}$ ) shallow landslides were created. The mean distance of bedload transport was similar ( $t$-test, $p=0.05$ ) in most of the windthrow-affected and control catchments. The mapping of channels revealed many cases of root plates fallen into a channel and pits created near a channel. A significant amount of woody debris delivered into the channels influenced the activity of fluvial processes by creating alternating zones of erosion and accumulation.

Keywords: Fluvial processes; Slope processes; Windthrow; Tree uprooting; Channel morphology; Tatra Mountains

\section{Introduction}

Strong wind events may result in extensive 
damage in forest stands and thereby the creation of large areas of uprooted trees. Such phenomena are frequent in mountain landscapes and have many geomorphic consequences. Among them some of the most important are: transporting sediment along slopes (Gabet et al. 2003; Gallaway et al. 2009; Constantine et al. 2012; Pawlik et al. 2016; Strzyżowski et al. 2018), redistributing coarse particles within soil and creating rock veneers (Small et al. 1990; Osterkamp et al. 2006), or increasing slope roughness (Lyford and MacLean 1966; Pawlik et al. 2013). However, the creation of a windthrow entails many environmental changes which potentially may impact the type and intensity of slope and fluvial processes acting within a catchment. Bare soil surfaces within windthrow pits which, after the uprooting of all the trees in a forest, may cover several percent of a windthrow area (Phillips et al. 2008; Strzyżowski et al. 2016), may be supposed to increase the delivery of sediment from slopes into channels by intensified slope wash. Forest operations conducted after a windthrow, depending on the applied techniques of timber harvesting, may also reduce vegetation cover, and thus expose soil to erosion. Lack of roots strengthening the soil mantle may lead to an increase in the landsliding rate (Ziemer 1981). All those changes may cause an increased delivery of sediment into channels. It may also be expected that the lack of forest cover and presence of bare soil surfaces may alter the hydrosedimentary dynamics within a catchment and increase the intensity of fluvial processes.

The impact of such abrupt environmental changes on the types and intensities of processes within a catchment still remains unexplored. Kotarba (1970) hypothesized that the creation of a windthrow causes a short-term increase in the intensity of slope processes. Hancock et al. (2011), based on the results of a landscape evolution model, claimed that the presence of an extensive windthrow decreases erosion within a hillslope. This was also confirmed by their field investigation which did not show any significant erosion within created windthrow pits. Similar results were obtained by Pawlik (2012), who measured the erosion rate within windthrow sites by collectors installed below several root plates. It occurred that almost all of the accumulated material was composed of organic matter. Gerber et al. (2002) mapped all unvegetated surfaces present within a windthrow area in Switzerland. After 8 years, half of those surfaces were colonized by vegetation. However, in one of their study sites the area of unvegetated surfaces was increased by many shallow landslides created after a rainfall event. In the Karkonosze Mountains, Hasiński (1971), using sediment collectors installed within a channel, recorded significantly higher bedload transport in the section of a stream surrounded by a windthrow compared to the section located within a forest. Also, in some areas there were observations of the role of windthrows in increasing the amount of woody debris in valley bottoms, and delivering fine sediment into channels by root plates fallen into streams (Reid 1981; Grizzel and Wolff 1998; Strzyżowski et al. 2016).

In many logged areas there was an increase of sediment transported in channels after clearcutting operations (Megahan et al. 1995; Constantine et al. 2005). In most cases, however, a major role in that was played by sediment delivered from slopes, mainly by landslides and forest roads (Fredriksen 1970; Grant and Wolff 1991).

A foehn wind event which occurred in the Tatra Mountains in 2013 created large areas of uprooted trees which in some cases covered entire catchments. In effect, the close proximity of catchments affected and unaffected by the windthrow produced an opportunity to investigate the impact of extensive windthrow areas on the intensity of geomorphic processes within a catchment. We assumed that catchments affected by the windthrow would present a higher intensity of slope and fluvial processes compared to forested catchments. The aims of this study are: (1) to determine the potential impact of extensive windthrow areas on slope processes, especially shallow landsliding and surface erosion within windthrow pits and scars created by wood transport and (2) to evaluate changes in fluvial processes and channel morphology by a comparison of forested and windthrow-affected catchments characterized by similar morphological and environmental conditions. The comparison was made based on the geomorphological mapping of channels and monitoring the distances and sizes of transported bedload during flood events in the period 2018-2019.

\section{Study Area}

The field work was carried out in the Polish part of the Western Tatra Mountains (Carpathians), in the 
Tatra National Park. The Tatra Mountains, culminating at 2,663 $\mathrm{m}$ a.s.l., belong to the Alpine orogeny and feature a typical high-mountain character (Kotarba et al. 1987; Krzemień 1992). However, the northern periphery of the massif is characterized by a middle-mountain relief, including its characteristic fluvio-denudational morphology (Gorczyca et al. 2014). The study area is located at the lower part of the Kościeliska Valley $\left(49^{\circ} 16^{\prime} \mathrm{N}, 19^{\circ} 52^{\prime} \mathrm{E}\right)$ and includes the northern slope of the Western Tatra Mountains, descending steeply from 1100-1330 m a.s.l. to $930 \mathrm{~m}$ a.s.l.. The Kościeliska Valley has an asymmetrical channel pattern, whereby its eastern slopes tend to be undercut by its main stream. The valley floor is filled with fluvial and fluvioglacial alluvia. The geology of the area includes mostly limestone, dolomite, and marl from the Triassic, Jurassic, and Cretaceous, as well as limestone, shale, and conglomerate from the Eocene (Bac-Moszaszwili et al. 1979; Dąbrowska and Guzik 2015).

For $71 \%$ of days in a year, local precipitation conditions develop in Polar maritime air masses. This type of air mass produces heavy and intense precipitation (Niedźwiedź 2003). The mean annual rainfall within the studied area ranges from 1400 to $1600 \mathrm{~mm}$, and mean rainfall for the summer period (June-August) is between 530 and $680 \mathrm{~mm}$ (Hess 1974). The mean annual temperature is between $2^{\circ} \mathrm{C}$ and $4^{\circ} \mathrm{C}$, and the number of days with snow cover is up to 140 (Hess 1974; Niedźwiedź 1992). Foehn wind events, which frequently cause damage in forest stands of the study area, occur mostly during the period from October to May (Niedźwiedź 1992). The most important factor favouring the occurrence of foehn wind in the Tatra Mountains is the presence of atmospheric circulation forcing the flow of air from the South to the North. One of such foehn wind events occurred on 25 December 2013, and has led to the creation of extensive windthrow areas, the majority of which are located in the Kościeliska Valley.
Six second- to third-order catchments were selected for the purpose of this study. The selection was based mainly on the distribution of the damage during the windthrow in 2013. We searched for catchments which were severely affected by the windthrow. This condition was met only in 3 catchments (W1, W2, W3; called windthrow-affected catchments), located on the left side of the Kościeliska Valley, in which the windthrow affected from $34 \%$ up to $94 \%$ of their area (Fig. 1). On the other side of the Kościeliska Valley, there were three catchments ( $\mathrm{C} 1$, $\mathrm{C}_{2}, \mathrm{C}_{3}$; called control catchments) in which most of their area was forested. Four out of six studied catchments (W1, W2, C2, C3) are very similar to each other in the aspect of their area, length of the main channel, and relative height (Table 1). The lowest values of those parameters are observed in catchment $\mathrm{C} 1$, and the highest in catchment $\mathrm{W}_{3}$, whose morphometric parameters are substantially greater than in any other studied catchment. From those six catchments 10 sub-catchments were selected for the purpose of a comparison of bedload transport intensity between windthrow and forested areas. The morphometric parameters of those sub-catchments are listed in Table 2, and the method of their selection is described in detail in the first paragraph of section 3.2 .

The studied catchments show the typical features of young river valleys with diversified depth and an uneven slope. Their upper sections are bowl-shaped. The valleys are wider within softer substratum rock, including marls and conglomerates, and narrower down in the gap sections of resistant limestone and dolomite (Dąbrowska and Guzik 2015). During the Pleistocene and Holocene, the valleys were periodically filled with debris, which was systematically removed from their bottoms and has built torrential fans at their mouth sections. In the studied area, the dominant types of soils are CambicRendzic Leptosols and Eutric Cambisols, and their

Table 1 Basic characteristics of the studied catchments.

\begin{tabular}{|l|l|l|l|l|l|l|}
\hline Parameter & Catchment & & & \\
\hline Area (ha) & W1 & W2 & W3 & C1 & C2 & C3 \\
\hline Main channel length (m) & 26 & 16 & 80 & 9 & 19 & 17 \\
\hline Elevation (m a.s.l.) & 573.1 & 439.8 & 1153.2 & 277.5 & 506.1 & 523.1 \\
\hline Area of forest (\%) & $937-1199$ & $939-1203$ & $947-1334$ & $948-1137$ & $950-1251$ & $964-1266$ \\
\hline Area of windthrow (\%) & 6 & 1 & 23 & 100 & 70 & 73 \\
\hline${\text { Average slope inclination }\left(^{\circ}\right)}^{\circ}$ & 76 & 94 & 34 & 0 & 22 & 20 \\
\hline Bedrock type $^{\text {a }}$ & 23.7 & 25.9 & 31.0 & 28.6 & 26.1 & 31.0 \\
\hline
\end{tabular}




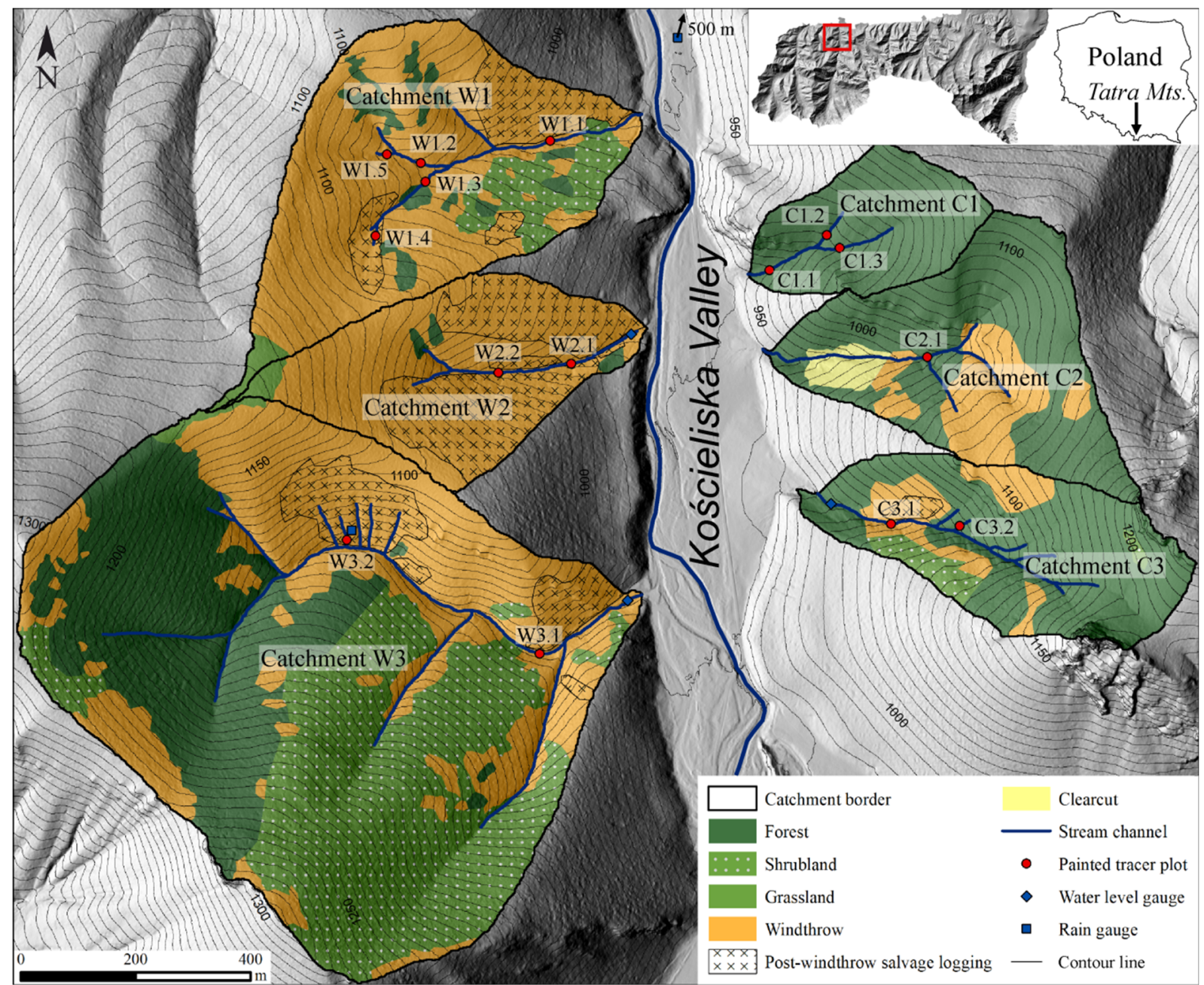

Fig. 1 Location of the studied valleys, painted tracer plots, and rainfall and water level gauging stations. One of the rain gauges belonging to the Institute of Meteorology and Water Management - the National Research Institute was located $500 \mathrm{~m}$ north of the studied area, as indicated by the arrow in the northern part of the map.

Table 2 Morphometric and environmental parameters of 5 pairs of catchments in which a comparison of bedload transport intensity was made.

\begin{tabular}{|c|c|c|c|c|c|c|c|c|c|c|}
\hline \multirow{2}{*}{ Parameter } & \multicolumn{2}{|l|}{ Pair 1} & \multicolumn{2}{|l|}{ Pair 2} & \multicolumn{2}{|l|}{ Pair 3} & \multicolumn{2}{|c|}{ Pair 4} & \multicolumn{2}{|l|}{ Pair 5} \\
\hline & W1.4 & C1.2 & W1.5 & C1.3 & W3.2 & $\mathrm{C}_{3.2}$ & W1.2 & C1.1 & W2.1 & C2.1 \\
\hline Area (ha) & 1.8 & 1.1 & 1.9 & 3.9 & 1.0 & 0.5 & $7 \cdot 3$ & 7.8 & 12.3 & 10.5 \\
\hline Average slope $\left(^{\circ}\right)$ & 20 & 28 & 25 & 28 & 31 & 31 & 23 & 29 & 26 & 25 \\
\hline Total channel length (m) & 10.3 & 36.3 & 11.1 & 24.2 & 40.2 & $25 \cdot 3$ & 145.1 & 234.8 & 331.3 & 320.6 \\
\hline Channel density $\left(\mathrm{m} \mathrm{ha}^{-1}\right)$ & 5.7 & 31.8 & 5.7 & 6.2 & 38.7 & 52.0 & 19.9 & 30.0 & 26.9 & 30.5 \\
\hline Average channel slope $\left(^{\circ}\right)$ & 24 & 25 & 19 & 22 & 34 & 32 & 19 & 22 & 23 & 20 \\
\hline Area of windthrow (\%) & 76 & 0 & 100 & O & 100 & 42 & 90 & O & 95 & 22 \\
\hline Area of forest (\%) & O & 100 & o & 100 & 0 & 58 & 10 & 100 & 2 & 78 \\
\hline
\end{tabular}

depths usually do not exceed $1 \mathrm{~m}$ (Skiba 2002).

After the windthrow in catchments $\mathrm{W}_{1}, \mathrm{~W}_{2}, \mathrm{~W}_{3}$, and in some places of catchment $\mathrm{C}_{3}$ salvage logging operations were conducted (see "Post-windthrow salvage logging" on Fig. 1). This included sawing off the trunks of trees at their bases and transporting them into the bottom of the Kościeliska Valley using a cable-crane. During this transport one side of a trunk was in contact with the slope surface which led to the creation of several linear erosion scars. In one of the valleys (W3) some of the trees were logged and stored inside the valley. They were then loaded on trucks and transported outside the catchment using its main channel as a road. Additionally at some places in catchment $\mathrm{C}_{2}$, the logging of trees affected by bark beetle was conducted (see "Clearcut" on Fig. 1). All of 
those forest operations produced large amounts of logging slash which was left on slopes and in channels.

\section{Methods}

\subsection{Slope processes and channel structure}

To determine if the creation of the extensive windthrow areas in 2013 increased the activity of slope processes and enabled the delivery of sediment into channels of the studied catchments, the following methods were applied in three windthrow-affected catchments (W1, W2, W3). The monitoring of landslide activity in the period 2015-2019 was conducted by visiting the catchments year by year during that period and mapping all newly created landslides. Also, windthrow pits were mapped in search of any signs of erosion activity within them. We assumed that pits may intercept subsurface flow within their upslope side, possibly resulting in the initiation of gullying and transporting sediment beyond them. It was supposed that such phenomena, if present, would occur most frequently within convergent slopes, which tend to concentrate water, so the mapping was done within $\mathbf{1 . 2}$ ha area of convergent slopes located within the windthrow. Additionally, we mapped all the linear erosion scars created by the transport of trunks during salvage logging.

To recognize the structure of the channels in the studied valleys, geomorphological mapping of stream channels within all six studied catchments was carried out. The channels were divided into sections which were $30 \mathrm{~m}$ long in first-order valleys, $50 \mathrm{~m}$ long in second-order valleys, and $100 \mathrm{~m}$ long in third-order valleys. To collect the data, a special log was prepared. The $\log$ covered the following four groups of data recorded for each channel section: (1) general information, (2) valley floor parameters, (3) channel and sediment parameters, and (4) impact of the 2013 windthrow on the channel. Principal log entries included information on geographic location, geological structure, valley floor and channel parameters, channel forms, cross sections, longitudinal profile, banks, floor type (rock floor, wood debris, pools and steps), and coarse sediment size.

\subsection{Monitoring of bedload movement}

Each studied catchment was divided into subcatchments for which their morphometric parameters were calculated using 1-m resolution Digital Elevation Model (Head Office of Geodesy and Cartography 2019a). The parameters included: area, mean slope inclination, density of channels (in $\mathrm{m} \mathrm{ha}^{-}$ 1), and mean slope of channels. Also, for all subcatchments, the percentage of their area covered by forest was calculated based on an orthophoto taken in 2017 (Head Office of Geodesy and Cartography 2019b). Five pairs of catchments were selected for the purpose of a comparison of the intensity of bedload transport between windthrow-affected and control catchments (Table 2). Three of the pairs were firstorder catchments and two of the pairs were secondorder catchments. The primary criterion of selecting catchments within each pair was land use, i.e. one of the catchment had to be forested, and the other had to be affected by windthrow. A secondary criterion included morphometric parameters of the 'paired' catchments. In most cases of those pairs we were able to select catchments in which all the measured parameters were similar. However, in particular pairs of catchments, some of the parameters may have varied, because there were limited cases of catchments which were similar geomorphologically, but differed in land use.

Within each of those catchments a painted tracers plot was established (Fig. 1). This was done by selecting 50-180 particles of sizes $1-38 \mathrm{~cm}$ (b-axis) from the channel, painting them, and placing them in the channel after they were dry in a row perpendicular to the channel. In most cases a plot was installed in the lower part of a given catchment, but, in some cases it was located in the middle part of a catchment. This is why the morphometric parameters shown in Table 2 were in some cases calculated for the part of a catchment which was located above a given plot of painted tracers. Additional painted tracer plots (W1.1, W1.2, W2.2, W3.1, and $\mathrm{C}_{3.1}$ ) were established in the catchments $\mathrm{W}_{1}, \mathrm{~W}_{2}, \mathrm{~W}_{3}$, and $\mathrm{C}_{3}$. Those plots were not used to make comparisons between the transport intensity in windthrow-affected and control catchments, but were created in order to improve the recognition of transport intensity in longitudinal profiles of the studied valleys.

The measurements were made in 2018 and 2019. In total six hydro-meteorological events were recorded during that period. Measurements were conducted 4 times, which resulted in four separate monitoring periods (time between deployment of 
tracers until measurements) of bedload transport: monitoring period 1 (25.05.2018 - 08.08.2018), monitoring period 2 (08.08.2018 - 17.10.2018), monitoring period 3 (07.06.2019 - 28.08.2019), and monitoring period 4 (28.08.2019 - 15.11.2019). During each measurement, distances and mean diameters of all the moved particles were measured. Particles which were not transported were counted in order to calculate the recovery rate. After measuring all the moved particles the plots were reestablished. In cases in which recovery rate was less than $100 \%$ the colour of the paint within that plot was changed in order to avoid sampling unrecovered tracers during further measurements.

Transport in windthrow-affected and control catchments was compared by analyzing transport curves presenting maximum transport distances in each catchment for each monitoring period separately, and by comparing mean transport distances for all events together, using the t-test $(p=0.05)$. Variables containing the distances of transport for each catchment were not normally distributed, and therefore, a transformation $\left(\log _{10}\right)$ was applied. After that most of the variables were still not-normally distributed, however, the skewness of each variable was significantly reduced, and ranged between 0.15 and 0.75 .

Rainfall data for 2018 were provided by the station belonging to the Institute of Meteorology and Water Management - the National Research Institute located at the foreland of the Tatra Mountains, in close proximity to the studied valleys ( $<1 \mathrm{~km})$. In 2019 rainfall was measured by a tipping-bucket rain gauge with Odyssey data logger installed in catchment W3. In order to determine flow rates in the studied valleys Thomson v-notch weirs were installed in catchments $\mathrm{W}_{2}, \mathrm{~W}_{3}$, and $\mathrm{C}_{3}$. Water levels were recorded by OTT ECOLOG 800 (GPRS) and OTT ECOLOG 500 water level loggers with a resolution of 10-minutes. Weirs and loggers were initially installed also in catchments $\mathrm{C} 1$, and $\mathrm{C}_{2}$, but the data from those catchments are only fragmentary because of the frequent jamming of a weir by fine wood branches in catchment $\mathrm{C} 1$ and the necessity of removing the equipment several times during forest operations in catchment $\mathrm{C} 2$.

\section{Results}

\subsection{Activity of slope processes}

During the period 2015-2019 five small shallow landslides took place between 2015 and 2017. Three of them took place in catchment $\mathrm{W}_{3}$, and their total area did not exceed $50 \mathrm{~m}^{2}$. Two of the landslides occurred in catchment W1, and their area equalled $31 \mathrm{~m}^{2}$. Each landslide was created near the bottom of the valley, and in two cases colluvial masses reached the channel. No landslides were noted in catchment W2.

Totally 1.2 ha of convergence areas located within the windthrow were mapped. Within those areas $15^{2}$ windthrow pits were identified. All of the pits were to some extent vegetated: in $47 \%$ of them vegetation covered their whole surface. In $30 \%$ of the pits signs of modelling of their upslope side by superficial processes (mostly soil slumping) were noted. In 10\% of all mapped pits $(15 \%, 10 \%$, and $5 \%$ of pits located in catchment $\mathrm{W}_{1}, \mathrm{~W}_{2}$, and $\mathrm{W}_{3}$, respectively) there were apparent signs of interception of subsurface flow by the upslope side of the pits. Those signs, however, were only local, and did not show any transport of sediment outside of the pits.

As a result of salvage logging operations 7 erosion scars ranging in length from 56 to $329 \mathrm{~m}(1036 \mathrm{~m}$ in total) were created. Their average width is $0.8 \mathrm{~m}$ and their average depth is $0.15 \mathrm{~m}$. None of those scars was directly connected to a channel. During mapping in 2016 the scars were vegetated along most of their length (68\%). In 2017 the length of vegetated scars had increased to $76 \%$.

\subsection{Channel characteristics}

Most of the mapped channel parameters are similar in windthrow-affected and control catchments. Both types of catchments have similar mean bed material sizes which range between 7.2 and $11.8 \mathrm{~cm}$ (Table 3). The amount of channel steps in the studied catchments ranges in most cases from 8 and 12 steps per $100 \mathrm{~m}$ of channel length. Only in the case of catchment W1 is it notably lower, equaling 5.8 steps per $100 \mathrm{~m}$ of channel length, which may be connected with more rounded pebbles resulting from conglomerate bedrock.

Large amount of different-sized woody debris was observed in the studied channels. Large woody debris (LWD) was delivered into the channels of catchments $\mathrm{W}_{1}, \mathrm{~W}_{2}, \mathrm{~W}_{3}, \mathrm{C}_{2}$, and $\mathrm{C}_{3}$ mainly in a form of trunks, log jams (fragments of trunks, branches, twigs, and roots), and, to a lesser extent, whole trees with their roots. The accumulation of woody debris in 
Table 3 Parameters of the channels of the studied catchments.

\begin{tabular}{|c|c|c|c|c|c|c|}
\hline \multirow{2}{*}{ Parameter } & \multicolumn{6}{|c|}{ Catchment } \\
\hline & W1 & W2 & W3 & $\mathrm{C} 1$ & $\mathrm{C} 2$ & $\mathrm{C}_{3}$ \\
\hline Mean bed material size $(\mathrm{cm})$ & 10.3 & 9.0 & 9.4 & 9.0 & 11.8 & 7.2 \\
\hline Maximum bed material size $(\mathrm{cm})$ & $33 \cdot 3$ & 30.1 & 45.9 & 31.8 & 41.8 & 31.4 \\
\hline Channel steps ( $n$ per $100 \mathrm{~m}$ ) & 5.8 & 8.6 & 9.7 & 10.0 & 7.2 & 12.2 \\
\hline Organic channel steps ( $n$ per $100 \mathrm{~m})$ & 3.3 & 5.8 & 1.5 & 2.4 & 2.6 & $5 \cdot 9$ \\
\hline Woody-debris (\% of channel surface) & 25.0 & 46.7 & $15 \cdot 7$ & 14.4 & 58.0 & 41.4 \\
\hline Bedrock (\% of channel length) & 18 & 3 & 44 & 4 & 8 & 24 \\
\hline Bank undercuts $\left(\mathrm{m}^{2}\right)$ & 168.5 & 56.3 & 367.5 & $44 \cdot 3$ & 93.2 & 68.2 \\
\hline Windthrow pits adjacent to the channel $\left(\mathrm{m}^{2}\right)$ & 10.4 & 25.6 & 12.4 & 2.9 & 0 & 14.2 \\
\hline
\end{tabular}
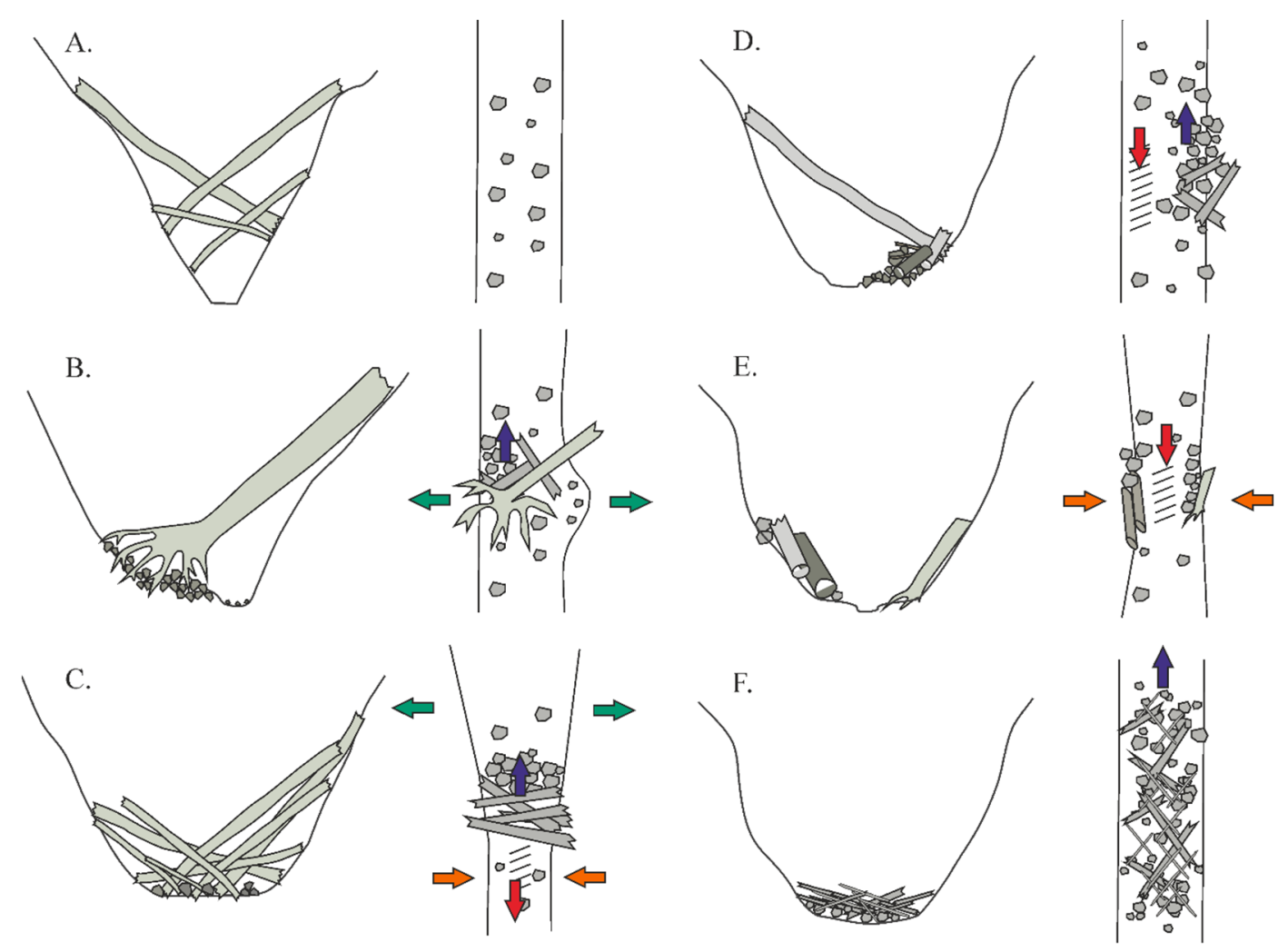

Direction of changes in the shape of the channel:

$$
\begin{aligned}
& \forall \text { deepening } \Rightarrow<\text { narrowing } \\
& \wedge \text { accumulating } \leftrightarrow \Leftrightarrow \text { widening }
\end{aligned}
$$

Fig. 2 Different patterns of modelling a channel affected by different types of woody debris. Large woody debris (LWD) hung over a channel (A). A whole tree fallen into a valley bottom damming one side of a channel (B). Deposition of LWD in the channel damming the whole channel width (C). Accumulation of fine woody debris (FWD) within one side of a channel forced by a partly suspended tree trunk (D). LWD blocking both sides of a channel (E). FWD spread around the entire surface of a channel (F).

the studied channels is different. It may hang over a channel (Fig. 2A) or be deposited in a channel (Fig. 2B-E). Woody debris, together with mineral debris, may entirely (Fig. 2B, C) or partly (Fig. 2D, E) dam a channel. As a result of logging operations, the channels of all windthrow-affected catchments and control catchments $\mathrm{C}_{2}$ and $\mathrm{C}_{3}$ were filled with a significant amount of fine woody debris (FWD; Fig. 2F) composed of logging slash. Although it did not play a significant morphogenetic role, in many cases initially it covered the entire surface of a channel or was concentrated in large clusters (Fig. 3). In effect, the amount of woody debris in the channels is high both in windthrow-affected catchments (25-47\% of 


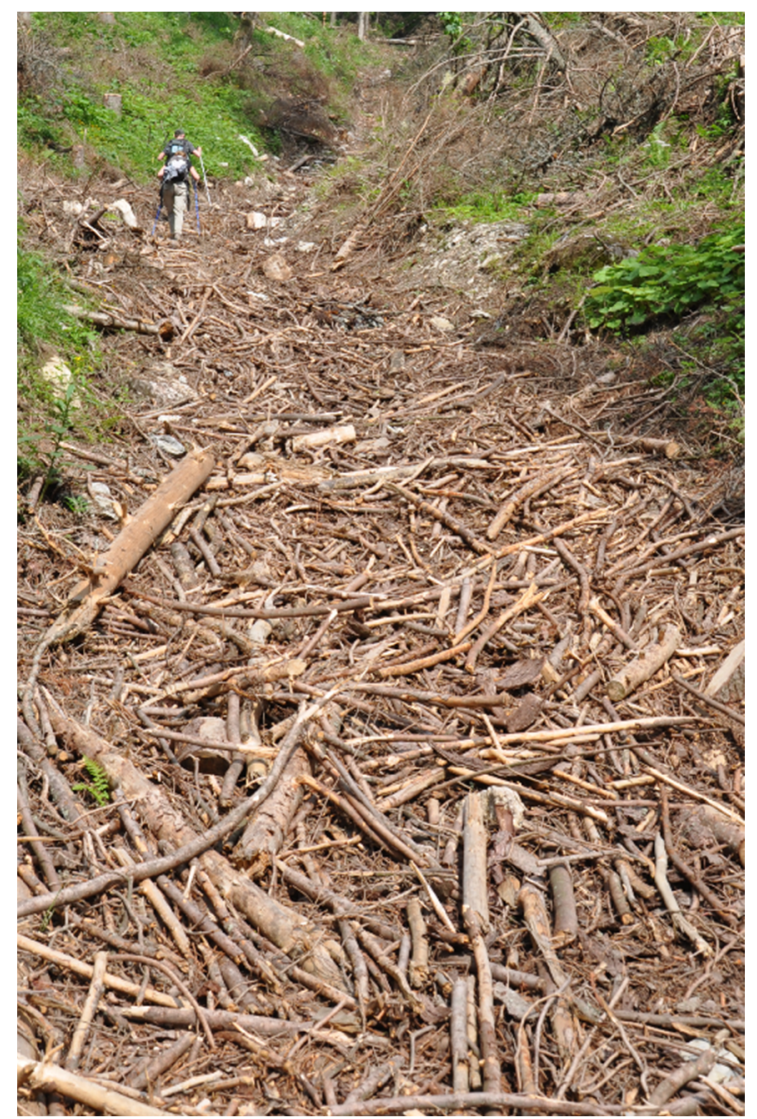

Fig. 3 Photo of a channel in catchment $\mathrm{C} 2$ taken after in 2018, after logging trees affected by bark beetle.

the surface of a channel, except from catchment $\mathrm{W}_{3}$, where woody debris was already removed by the high energy of fluvial processes) and in control catchments $\mathrm{C}_{2}$ and $\mathrm{C}_{3}$ (41\%-58\% of the surface of a channel). The lowest amount of woody debris (14\% of the surface of a channel) was observed in control catchment $\mathrm{C} 1$ which is $100 \%$ forested and had not been subjected to any forest operations in recent years.
Woody-debris channel steps constitute from $16 \%$ to $66 \%$ of all recorded channel steps. In windthrowaffected catchments $\mathrm{W}_{1}$ and $\mathrm{W}_{2}$, the amount of woody-debris steps is higher (3.3-5.8 steps per $100 \mathrm{~m}$ of channel length) compared to the control catchments $\mathrm{C}_{1}$ and $\mathrm{C} 2$ (2.4-2.6 steps per $100 \mathrm{~m}$ of channel length). The greatest number of woodydebris steps (5.9 per $100 \mathrm{~m}$ of channel length) was noted in control catchment $\mathrm{C}_{3}$. The lowest number of organic steps (1.5 per $100 \mathrm{~m}$ of channel length) was recorded in windthrow-affected catchment $\mathrm{W}_{3}$, where high-energy fluvial processes have removed most of the organic material.

The total area of bank undercuts equaled 168.5 $\mathrm{m}^{2}, 56.3 \mathrm{~m}^{2}$, and $367.5 \mathrm{~m}^{2}$ in catchments $\mathrm{W} 1, \mathrm{~W} 2$, and $\mathrm{W}_{3}$, respectively. In the same catchments, the area of windthrow pits which were created directly near channels and from which sediment was able to enter a channel was $10.4 \mathrm{~m}^{2}, \quad 17.9 \mathrm{~m}^{2}$, and $12.4 \mathrm{~m}^{2}$, respectively. Since those windthrow pits also may be subject to fluvial erosion it can be said that their creation "expanded" the area of bank undercuts by respectively $6 \%, 32 \%$, and $3 \%$ in catchments $\mathrm{W}_{1}, \mathrm{~W} 2$, and W3. In fact, only the lowest part of a pit adjacent to a channel may be eroded by a stream, but the rest of its surface is subject to sheet wash during a rainfall and also delivers sediment into a channel. Also 16 cases of root plates which have fallen into channels were noted which also may contribute to the increase of sediment transport within streams.

\subsection{Rainfall events and bedload transport intensity}

During the 2 years of monitoring the intensity of

Table 4 Results of the bedload transport measurements presented for first-, second-, and third-order valleys for each measurement.

\begin{tabular}{|c|c|c|c|c|c|}
\hline $\begin{array}{l}\text { Measurement } \\
\text { No. }\end{array}$ & $\begin{array}{l}\text { Catchment } \\
\text { order }\end{array}$ & $\begin{array}{l}\text { Transported } \\
\text { tracers (\%) }\end{array}$ & $\begin{array}{l}\text { Recovered } \\
\text { tracers (\%) }\end{array}$ & $\begin{array}{l}\text { Maximum } \\
\text { distance (m) }\end{array}$ & $\begin{array}{l}\text { Maximum size } \\
\text { (cm) }\end{array}$ \\
\hline \multirow[t]{3}{*}{190.} & First-order & $58-100$ & $27-94$ & 14.5 & 15 \\
\hline & Second-order & $37-92$ & $17-50$ & 31.5 & 26 \\
\hline & Third-order & $83-97$ & $20-25$ & 104.9 & 36 \\
\hline \multirow{3}{*}{2} & First-order & $5-40$ & $80-100$ & $5 \cdot 3$ & 8 \\
\hline & Second-order & $7-45$ & $75^{-100}$ & 6.8 & 9 \\
\hline & Third-order & $20-22$ & $75-94$ & 33.8 & 16 \\
\hline \multirow{3}{*}{3} & First-order & $0-22$ & 20-100 & 0.7 & 5 \\
\hline & Second-order & $0-49$ & $75-100$ & 2.6 & 11 \\
\hline & Third-order & $9-15$ & $43-93$ & 3.8 & 10 \\
\hline \multirow{3}{*}{4} & First-order & $0-7$ & $75^{-100}$ & 0.3 & 8 \\
\hline & Second-order & $0-33$ & $94-100$ & 2.8 & 8 \\
\hline & Third-order & $17-39$ & $88-100$ & 3.8 & 9 \\
\hline
\end{tabular}




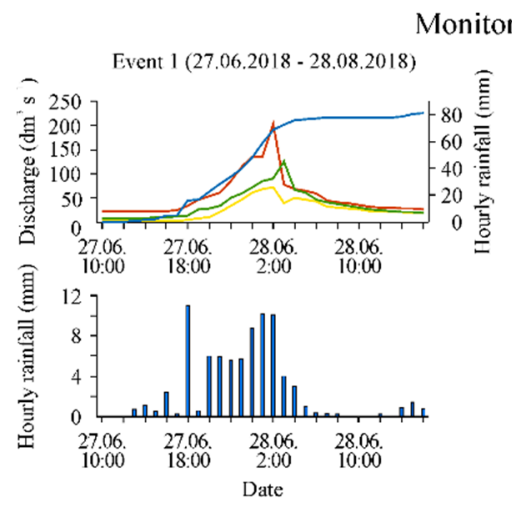

Monitoring period 1

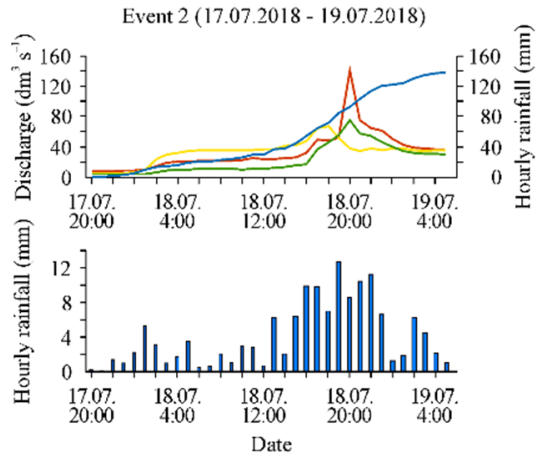

Monitoring period 3
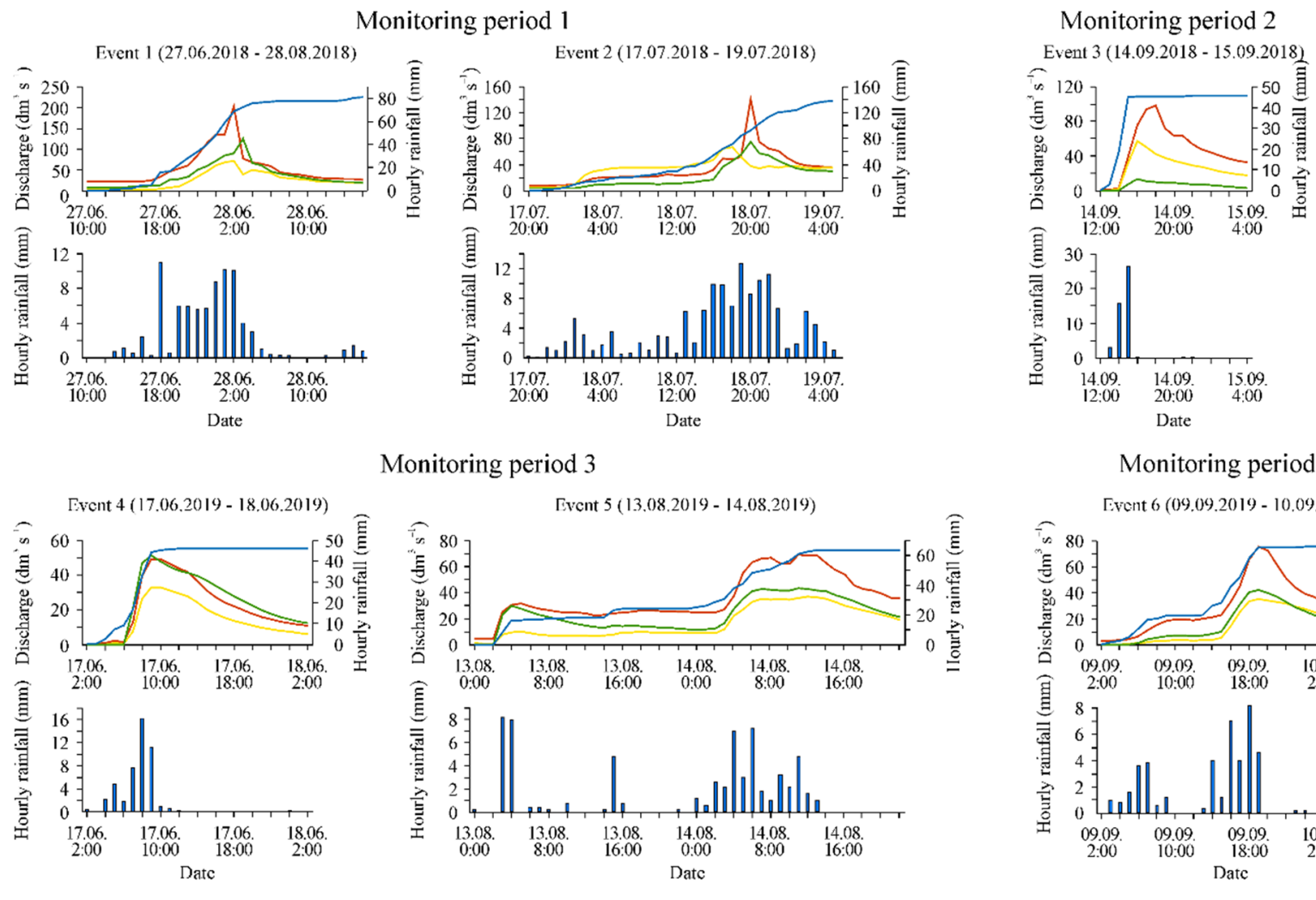

Monitoring period 4

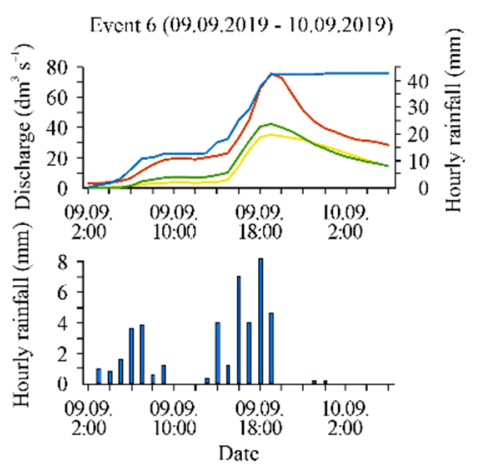

Catchment w2

- Catchment C3

- Cunnulative rainfall

Fig. 4 Graphs showing absolute and cumulative values of hourly rainfall $(\mathrm{mm})$ and hourly values of $\operatorname{discharge}\left(\mathrm{dm}^{3} \mathrm{~s}^{-1}\right)$ during six hydro-meteorological events recorded in the period of bedload transport measurements (2018-2019).

bedload transport using painted tracers, several hydro-meteorological events have occurred. The magnitude of bedload transport was determined by both the intensity of a given event (Fig. 4) and the order of a catchment (Fig. 5, Table 4).

The first period of monitoring bedload transport included two rainfall events which resulted in the highest discharge noted during the whole period of conducting the monitoring. During the first of those events $67.8 \mathrm{~mm}$ of rain fell in a period of 10 hours which caused a discharge reaching 71, 202, and 123 $\mathrm{dm}^{3} \mathrm{~s}^{-1}$ in catchments $\mathrm{W}_{2}, \mathrm{~W}_{3}$, and $\mathrm{C}_{3}$, respectively (Fig. 4). During the second event $98.1 \mathrm{~mm}$ of rain fell during a period of 21 hours, which resulted in lower discharges $\left(66,140\right.$, and $75 \mathrm{dm}^{3} \mathrm{~s}^{-1}$, respectively in catchments $\mathrm{W}_{2}, \mathrm{~W}_{3}$, and $\mathrm{C}_{3}$ ). This monitoring period caused the transport of $37 \%-100 \%$ of tracers for a maximum distance of $14.5 \mathrm{~m}, 31.5 \mathrm{~m}$, and $104.9 \mathrm{~m}$ in first-, second-, and third-order catchments, respectively (Table 4).

The third hydro-meteorological event (during the second monitoring period) was triggered by an intense rainfall of $45.1 \mathrm{~mm}$ during 3 hours. It caused an instant increase of discharges in the channels, which peaked at 56, 98 and $13 \mathrm{dm}^{3} \mathrm{~s}^{-1}$ in catchments $\mathrm{W}_{2}, \mathrm{~W}_{3}$, and $\mathrm{C}_{3}$, respectively. Its geomorphic effects were significantly weaker comparing to the previous events. From $5 \%$ to $45 \%$ of tracers were mobilized and the maximum distance of their transport ranged from $5.3 \mathrm{~m}$ in first- to $33.8 \mathrm{~m}$ in the third-order catchments.

The two next rainfall events which occurred during the third monitoring period, and the last rainfall event which took place during the fourth monitoring period, resulted in notably lower discharges in each of the monitored catchments. Those discharges did not exceed 40, 80, and $60 \mathrm{dm}^{3} \mathrm{~s}^{-1}$ respectively in catchments $\mathrm{W}_{2}, \mathrm{~W}_{3}$, and $\mathrm{C}_{3}$. Those events seemed to be close to the threshold of activating bedload transport. Respectively 22, 49, and 39 percent of tracers were transported in first-, second-, and thirdorder catchments, and the maximum transport distance did not exceed $1 \mathrm{~m}$ in first-order catchments and $4 \mathrm{~m}$ in third-order catchments.

Analysis of the hydrographs shows that during the three events $(4,5$, and 6, Fig. 4) peak discharge in all the monitored catchments occurred at the same time. Differences in the time of the maximum discharge between particular catchments were observed 

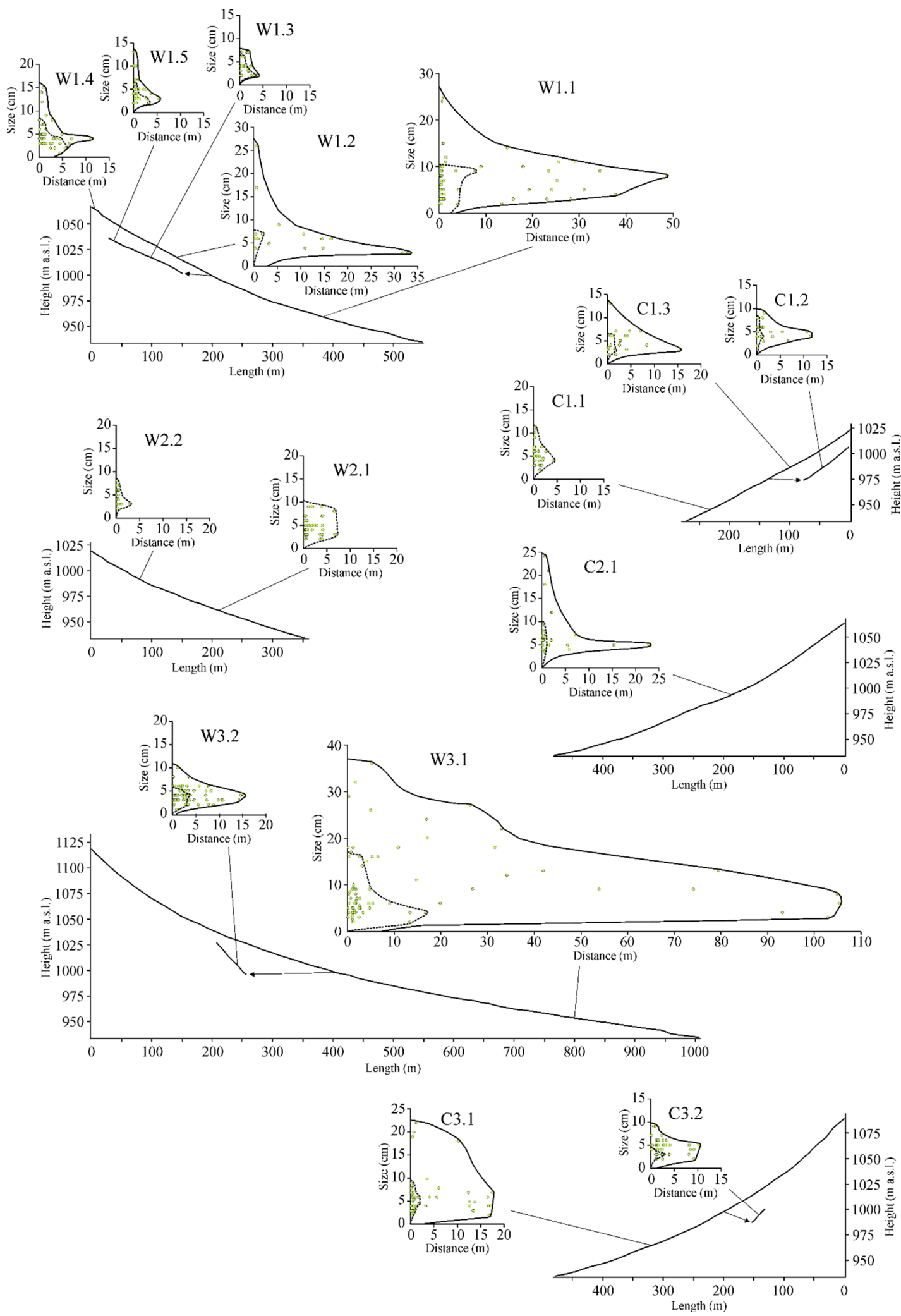

Fig. 5 Results of bedload transport measurements shown for all painted tracer plots. Each transport curve graph (particle size vs distance travelled) contains all the measurements collected for a given plot throughout 2 years of conducting the experiment. Dotted lines outline results for three measurements (excluding the first measurement which was not done for plots W2.1, W2.2, and C1.1 - see the methods section) and solid lines outline results for all four measurements. Locations of the plots are marked within longitudinal profiles of the studied channels. 
during events 1,2 , and 3 . Those differences, however, do not present any regularity, i.e. during each of those events peak discharge noted in one of the three monitored catchments was either before or after peak discharge noted in the two other monitored catchments (see Fig. 4).

\subsection{Bedload transport in windthrow-affected and control catchments}

The comparison of the intensity of fluvial transport in windthrow-affected and control catchments was done on an example of 10 catchments in which painted tracers plots were installed and which were put together in 5 pairs (windthrow-affected vs control). Three of the pairs were first-order catchments and two of the pairs were second-order catchments.

During the first monitoring period in two of the pairs (W1.4 vs $\mathrm{C} 1.2$ and $\mathrm{W}_{3} .2$ vs $\mathrm{C}_{3}$.2; first-order catchments) transport intensity within windthrowaffected and control catchments was similar (Fig. 6). In one of the pairs (W1.5 vs C1.3) transport intensity was greater in the control catchment compared to the windthrow-affected one. The pairs located in secondorder catchments are not compared for this period (see methods section). During the second monitoring period in four out of five pairs of catchments, tracers located within the windthrow-affected catchments showed longer distances of transport. Only in the case of one pair (W1.2 vs C1.1) was a higher transport distance recorded for tracers located within the control catchment. During the third monitoring period, in two pairs of catchments (W1.4 vs C1.2 and W1.5 vs C1.3) the transport was higher within the windthrow-affected catchments. Two of the pairs (W3.2 vs $C_{3} .2$ and W2.1 vs C2.1) showed similar transport distances, and one of the pairs (W1.2 vs C1.1) showed explicitly higher transport distance in the control catchment. During the fourth monitoring period in three pairs (W1.4 vs C1.2, W1.5 vs C1.3, and W1.2 vs C1.1) of catchments, higher transport intensity was observed within control catchments. In one of the pairs (W3.2 vs C3.2) there was no transport in both catchments and in another pair (W2.1 vs C2.1) the transport was greater in the windthrow-affected catchment.

If the intensity of transport in the same pair of catchments is analyzed over different monitoring periods, there is no consistent difference between a windthrow-affected and a control catchment. The largest inconsistency is observed in the pairs W1.4 vs C1.2 and W1.5 vs C1.3 where during some of the monitoring periods the transport was greater in the windthrowaffected catchments and during the others in the control catchments. In the case of the pair W2.1 vs C2.1 the transport was notably greater in the windthrow-affected catchment during the second and fourth monitoring period. However, during the third period the transport intensity in both catchments was similar. In the case of one pair of catchments (W1.2 vs C1.1) the transport intensity among all the monitoring periods was significantly greater in the control catchment. One of the pairs of catchments (W3.2 vs $\mathrm{C}_{3.2}$ ) presented relatively similar transport intensities during each period.

Comparison of the mean distance of bedload transport in windthrow-affected and control catchments shows that in two pairs of catchments significant differences $(p=0.05)$ in mean transport distance exist (Fig. 7). In one of those pairs the mean distance of transport is greater in a windthrowaffected catchment, and in the other - in a control catchment. In three other pairs there are no significant differences between windthrow-affected and control catchments.

\section{Discussion}

\subsection{Slope processes}

Within windthrow-affected slopes the most obvious features in which geomorphic processes may be intensified are pits which may cover several percent of a post-disturbance area (Phillips et al. 2008; Strzyżowski et al. 2016). Although such places may be expected to be especially prone to erosion (Kotarba 1970), studies on the activity of geomorphic processes within pits are rare. One of them is the study of Hancock et al. (2011) who did not observe any signs of significant erosion within pits. Moreover, their model-based simulations showed that erosion within a slope was reduced after the creation of pits and mounds which acted as sediment traps. Pawlik (2012) also did not observe any increase in the surface erosion within windthrow areas. In the studied catchments half of the mapped pits located on convergent slopes were fully vegetated, and only $10 \%$ of them showed signs of subsurface flow interception. In such cases there were no traces of transporting sediment outside of the pits or initiation of gully erosion. It is, therefore, expected that the occurrence of erosion within the pits located outside convergence 


\section{Period I}
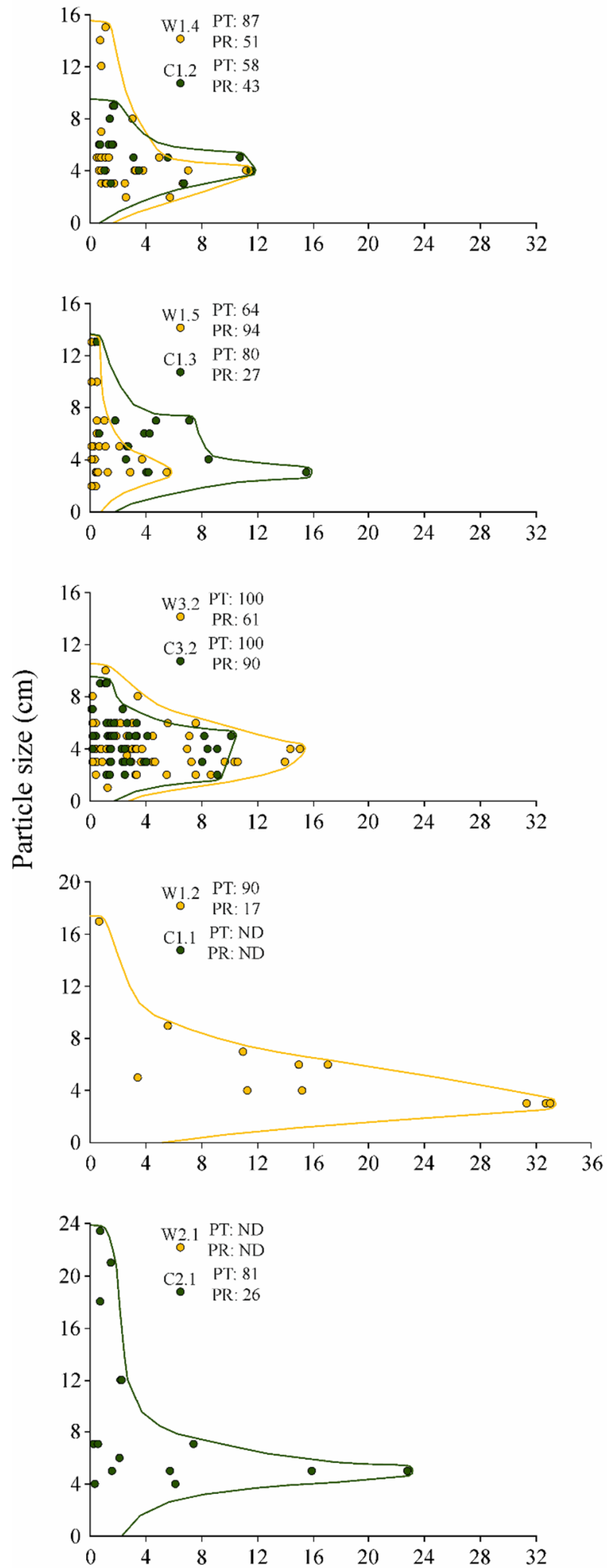

Period II
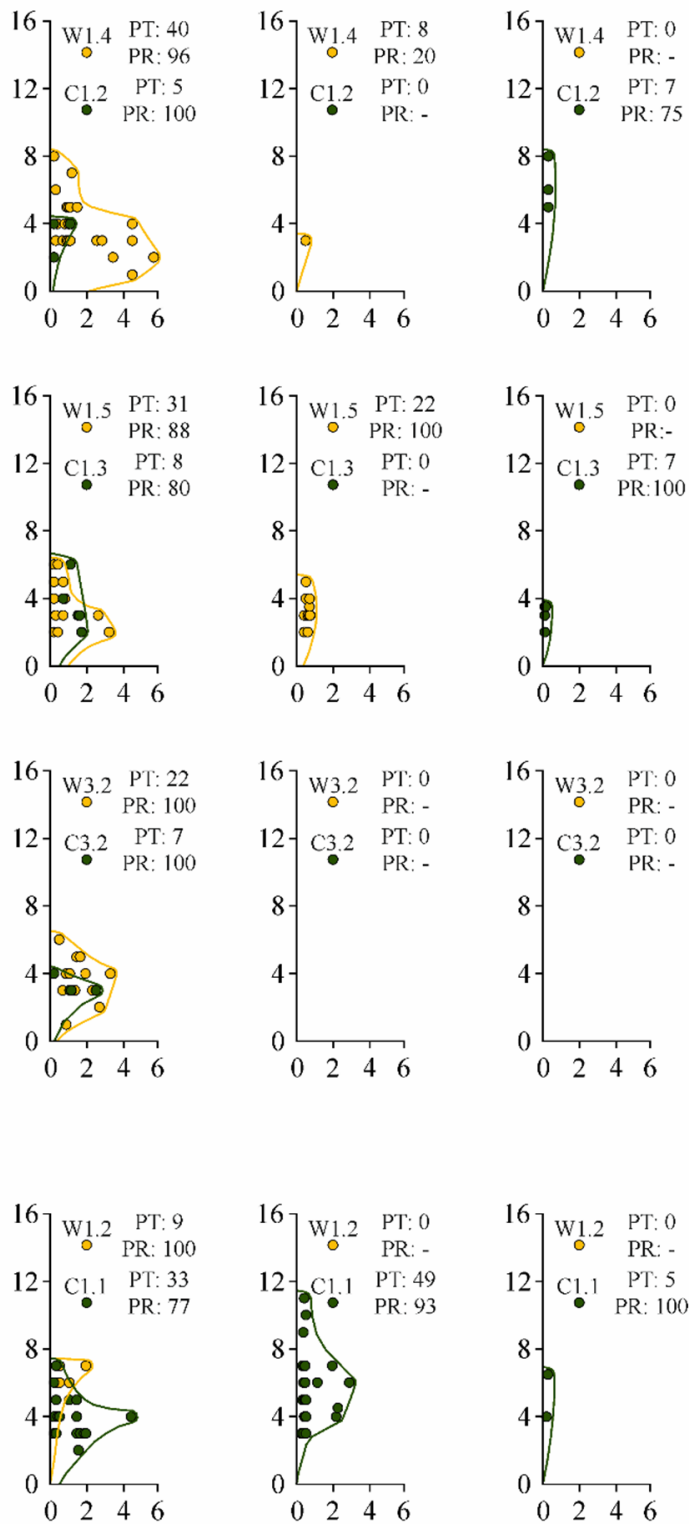

\section{Distance $(\mathrm{m})$}
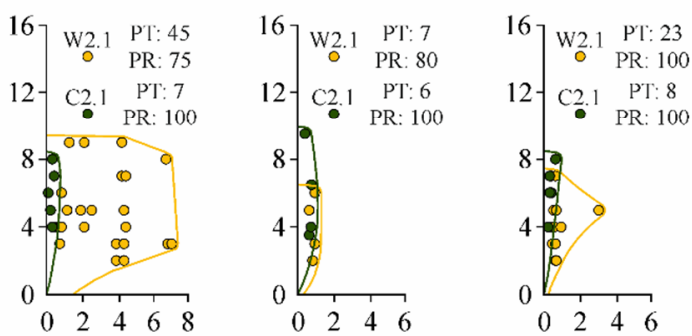

Fig. 6 Transport curve graphs (distance of a transported particle vs its diameter) for all 5 pairs of windthrow-affected and control catchments. Each "column" of graphs represents one measurement. 

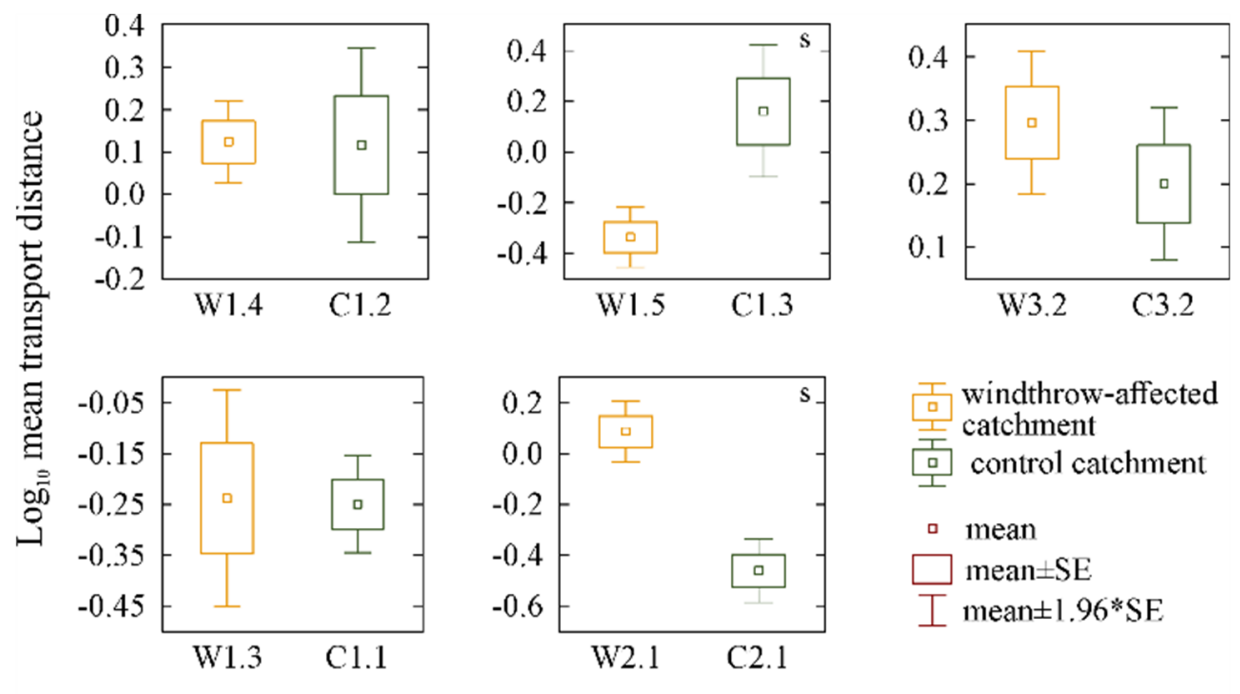

Painted tracers plot

Fig. 7 T-test plots showing differences in mean bedload transport distance between windthrow-affected and control catchments. Each mean is calculated based on all the measurements taken in 2018-2019 at a given plot. Pairs of catchments presented on upper plots are first-order catchments and pairs presented on the lower plots are secondorder catchments. Letter " $\mathrm{s}$ " in the upper corner of a plot indicates that means are significantly different at $p=0.05$.

areas is even less frequent. This may be confirmed by the study of Strzyżowski et al. (2016) who showed that among almost 500 pits mapped 1.5 years after the windthrow in catchment W2, only 5 presented signs of erosion within their upslope side and most of them were vegetated in at least in $30 \%$ of their area.

Besides the exposure of soil in windthrow pits, salvage logging operations conducted within thewindthrow led to the creation of linear erosion scars. In 2016, erosion scars created in catchments $\mathrm{W}_{1}, \mathrm{~W}_{2}$, and $\mathrm{W}_{3}$ were vegetated along most of their length and the amount of vegetation within them tended to increase with time. No gullying was observed at the surface of those forms, and none of those scars was directly connected to the channel. It is therefore suspected that those surfaces do not contribute to increased slope erosion.

In general, observations made during many field trips which began in 2015, showed that the slopes in the study area are rapidly colonized by vegetation. Observations from other areas confirm that, and show that created pits may become entirely vegetated in 5 years after a forest disturbance (Fischer et al. 2002; Wohlgemuth et al. 2002).

Since the loss of root reinforcement in soils, which is noted after logging, may significantly increase the intensity of shallow landsliding (Ziemer 1981; Jakob 2000; Guthrie 2002; Roering et al. 2003; Roberts et al. 2004; Imaizumi et al. 2008), one should also expect an increase in the landsliding rate at windthrow areas. However, there are few reports of landsliding intensity after a windthrow. Both Gerber et al. (2002) and McDonald (2011) showed an increased rate of landsliding within windthrow areas. On the other hand, Wohlgemuth et al. (2017) did not observe differences in the intensity of mass movements between windthrow and forested areas. In our study site in the period from 2015 to 2019 (2-6 years after the windthrow) only 5 small landslides have occurred, with a total area of $81 \mathrm{~m}^{2}$. Considering the sizes of the catchments it appears that the geomorphic significance of those forms is negligible. It is not clear why the intensity of landsliding was low after the windthrow. The effects of reduced root cohesion on the landsliding rate certainly depend on the susceptibility of a given area to mass wasting processes and in some cases they may be insignificant (Swanson and Dyrness 1975). Moreover, it has to be underlined that during the studied period rather low magnitude hydro-meteorological events occurred, the intensities of which were probably under the threshold of activating shallow landslides.

\subsection{Hydro-meteorological conditions and a comparison with an extreme event}

During the period of bedload transport monitoring, there were 3 events which produced a rainfall total of about $40 \mathrm{~mm}$. In most cases those events were close to the threshold of activating 


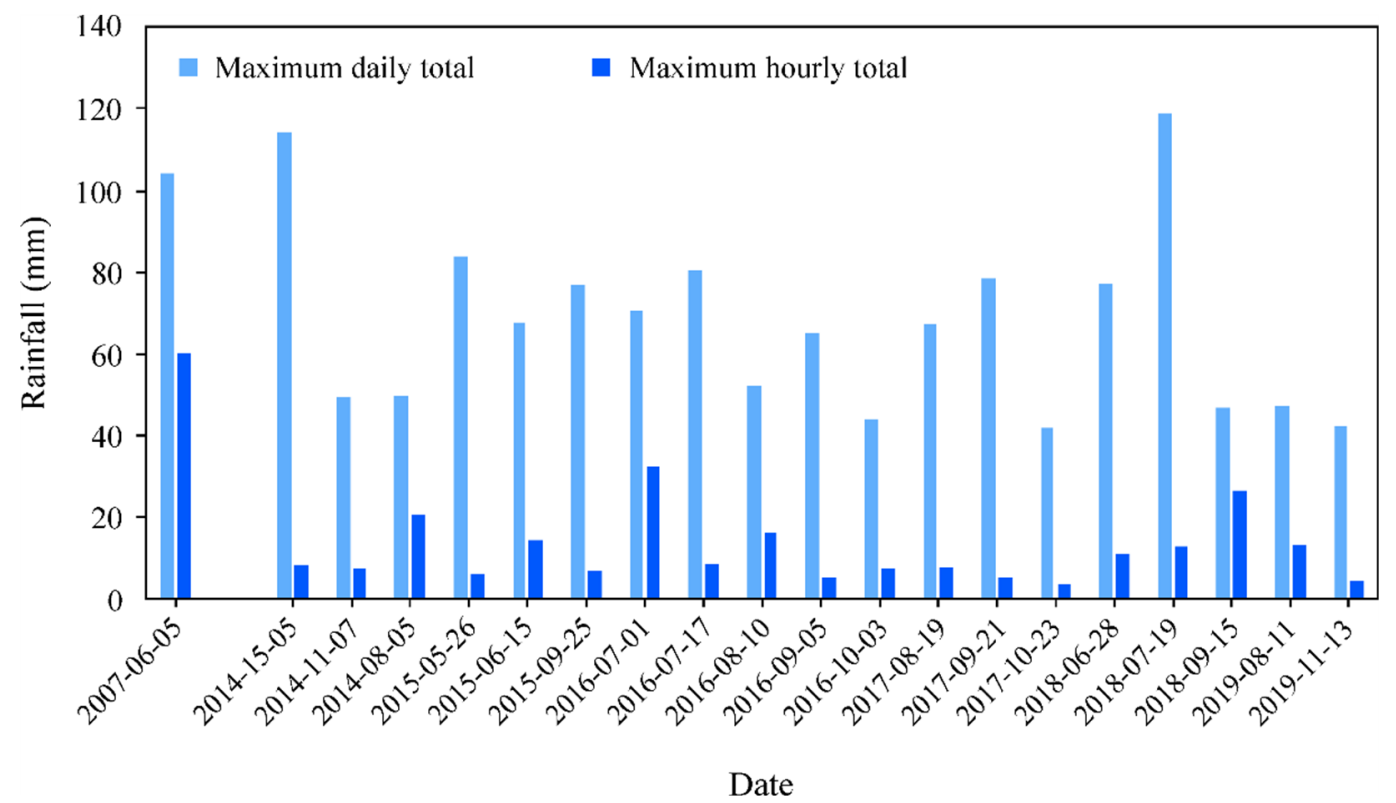

Fig. 8 Daily and hourly precipitation sums for all the rainfall events recorded in 2014-2019 during which the daily precipitation sum exceeded $40 \mathrm{~mm}$. Precipitation sums for the event in 2007 are presented for comparison.

bedload movement within channels. In the period from the windthrow event in December 2013 until the end of our field work in 2019 in total 19 events with daily precipitation sum exceeding $40 \mathrm{~mm}$ were noted (Fig. 8, the data source is the Institute of Meteorology and Water Management - National Research Institute). During 2 of those events (in 2014 and 2018) the daily precipitation sum significantly exceeded 100 $\mathrm{mm}$ and during one event (in 2016) the daily precipitation sum was $70.6 \mathrm{~mm}$, but maximum hourly rainfall reached $32.4 \mathrm{~mm}$. The event in 2018, which probably was the most intense event since the windthrow, resulted in the greatest transport of bedload in the studied valleys during the period of bedload transport measurements (2018-2019).

Nevertheless, high-magnitude geomorphic events occur in the studied area relatively frequently. One of such events occurred on June 5, 2007 (Gorczyca et al. 2014). The precipitation total of 104.2 $\mathrm{mm}$, with its highest intensity of more than $1 \mathrm{~mm}$ $\mathrm{min}^{-1}$ triggered numerous shallow landslides within slopes and high-energy fluvial processes within the valley bottoms of all the studied catchments, which at that time were $100 \%$ forested (Gorczyca et al. 2014). The average maximum sizes of bedload transported in particular sections of the studied valleys ranged between 30 and $60 \mathrm{~cm}$. In the left-side valleys (W1, $\mathrm{W}_{2}, \mathrm{~W}_{3}$ ) the maximum size of the transported bedload exceeded $60 \mathrm{~cm}$. The proportion of rocky floors was between $25 \%$ and $60 \%$ of the length of a given channel.

In the period of measuring bedload transport (2018-2019) no events similar in magnitude to that in 2007 occurred, and therefore, transformations of valley floors were significantly lower. During the highest-magnitude hydro-geomorphic event recorded in that period, in 2018, the sizes of transported bedload were up to $30-40 \%$ of those recorded in 2007 and the proportions of rocky floors in the length of the channels were $7-50 \%$ of those in 2007.

\subsection{Fluvial processes}

According to our knowledge there is no research on the intensity of fluvial processes within catchments affected by a windthrow. Only Hasiński (1971) made a short note in which he pointed out that bedload transport within a windthrow area was 77.6 times greater than within a forested area. A similar situation was frequently observed within logged catchments, where the amount of sediment, both bedload and suspended, transported in channels had increased by from several up to 100 times (Fredriksen 1970; Grant and Wolff 1991; Douglas et al. 1992; Constantine et al. 2005). It was shown that such a situation is caused by significant sediment delivery from slopes rather than by increased flows during storms (Megahan et al. 1995). Most of this delivery results from mass movements which are intensified by reduced root cohesion and from newly constructed forest roads 
(Fredriksen 1970; Grant and Wolff 1991; Constantine et al. 2005; Karwan et al. 2007). In the studied windthrow area, however, the delivery of sediment from slopes into channels in the period since the windthrow event, except from some places where uproots were created in the vicinity of channels, was rather negligible.

The intensity of bedload transport measured in the studied catchments was not clearly influenced by the windthrow. Despite the fact that catchments between which transport was compared are located in the closest vicinity and have similar morphometry and lithology, in all but one 'pair' of compared catchments the intensity of bedload transport differed. Those differences were, however, not consistent among the monitoring periods, which suggests that they were caused by factors other than the presence of windthrow or forest.

In the studies of the hydrological consequences of logging, it is underlined that the increase in peak flows in logged catchments is minor or it is notable only during the lowest flows, and it decreases with the intensity of a storm (Hewlett and Helvey 1970; Ziemer 1981; Wright et al. 1990; Lewis et al. 2001). It was shown that the impact on peak flows of unvegetated surfaces such as forest roads may be insignificant if they cover a small area $(<12 \%)$ of a catchment (Harr et al. 1975). In our study area, in catchment W2, where the windthrow covers almost $100 \%$ of the catchment, the total area of the catchment which was devoid of vegetation was assessed at $4.8 \%$ (Strzyżowski et al. 2016). It is probable, therefore, that the windthrow which occurred in the studied area had minor effects on the highest storm flows, and, thus on the energy of flowing water capable of transporting bedload. It certainly may be supposed that local differences in channel characteristics, rainfall distribution, or various local catchment parameters, play a greater role in differentiating the intensity of channel bedload transport than the presence of the windthrow.

\subsection{Role of woody debris}

Woody debris is an integral part of channels located in the forested part of the Tatra Mountains. Trees which have fallen into a stream notably affect fluvial processes (Gurnell et al. 2002). The type of woody debris (after Thévenet et al. 1998), its volume, and the place of its deposition in a channel, influence the distribution and sizes of channel forms (Gregory et al. 1985).

A significant amount of large woody debris (LWD) was delivered to the channels of the studied catchments by the windthrow in 2013 and subsequent forest operations. The morphogenetic role of woody debris in the studied channels is considerable and has led to their transformation. Depending on the type and amount of woody debris, it may affect the flow by damming (Fig. 2C) or narrowing (Fig. 2D, E) it. This causes erosion of channel banks above a dam (Fig. 2C) or erosion of a channel bank in the place where a dam has narrowed a stream flow (Fig. 2B). The latter case also results in an increase of channel bed erosion and creation of a narrow chute (Fig. 2D, E).

According to Nakamura and Swanson (1993) in first- and second-order streams, which have low channel width, LWD is generally not transported and occurs in the form of whole trees or their parts hung over a channel. A similar pattern was observed in the studied valleys (Fig. 2A). It has, however, to be assumed that the durability of dead wood is limited to 30-40 years (Wallace et al. 2001; Kaczka 2003). After that period tree trunks may break into smaller fragments and their remnants may fall into a channel contributing to damming effects and local accumulation.

Forming organo-mineral steps and potholes within streams leads to the creation of a step-like longitudinal channel profile (Keller et al. 1995). Such a pattern of modelling of the studied valleys was observed after the 2013 windthrow. Steps in the studied channels are rather large compared to those noted in other Carpathian Mountains ranges (Kaczka 2003). Their maximum heights range between $1.1 \mathrm{~m}$ and $2.0 \mathrm{~m}$, and their mean heights are from $0.48 \mathrm{~m}$ up to $0.85 \mathrm{~m}$. On average, $1.5-5.9$ woody-debris steps were noted along the $100 \mathrm{~m}$ of a channel length in the studied valleys. Those are rather high values which notably decrease transport of bedload and contribute to the development of sediment accumulation sites. The durability of fragments of trunks, branches, and wood jams is rather short compared to whole trunks, so their period of decomposition will be faster. This material is successively removed during flood events, and the greater the role of fluvial processes in a given section of a channel, the faster this happens. It may be clearly observed in the example of catchment $\mathrm{W}_{3}$ in which significant changes in the morphology of its main 

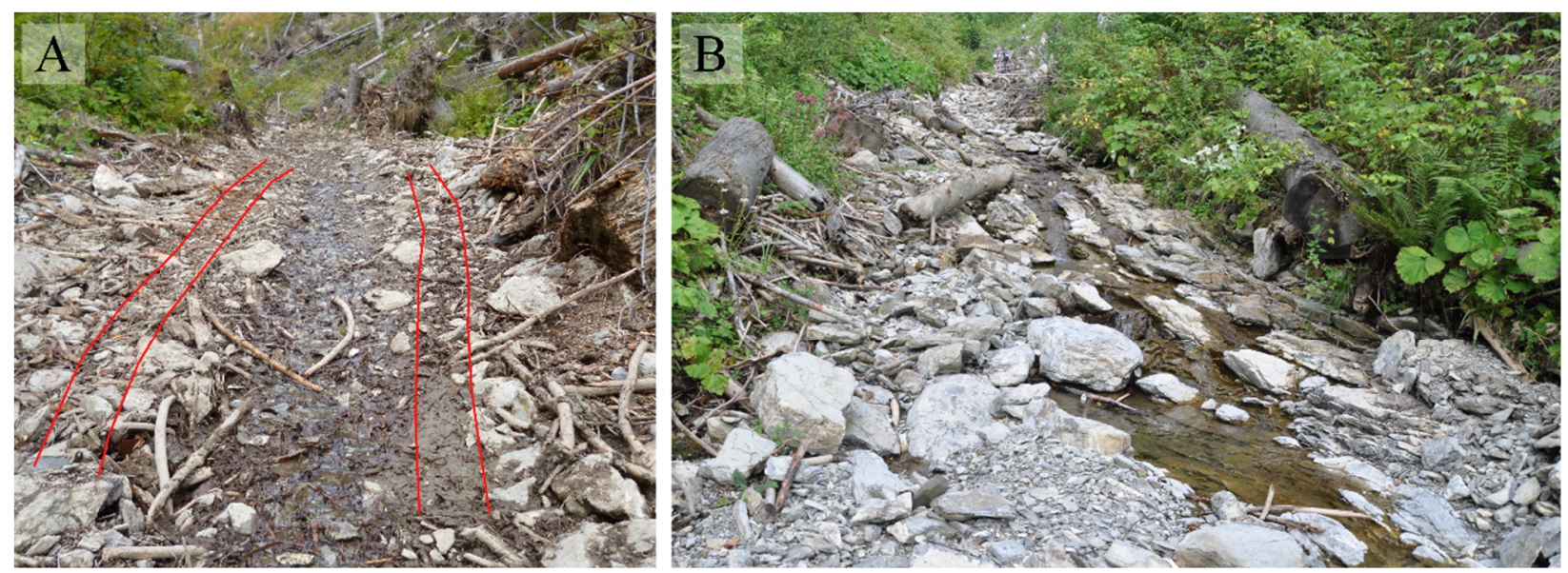

Fig. 9 Channel in catchment W3 in 2016, 2.5 years after the windthrow event; ruts created by vehicles are marked by dotted lines (A). The same section of the channel in 2018 (B).

channel were made by the accumulation of woody debris during windthrow and forest operations and by using the channel as a road for wood transport (Fig. 9A). By 2018 most of the FWD had already been removed and channel forms were created again (Fig. 9B). A similar trend of removing FWD from a channel may be observed in catchments $\mathrm{W} 1$, and $\mathrm{C} 2$. Along with the decomposition and removal of in-channel wood the step-like profile of the studied channels will be gradually degraded, and bedload sediment will be transported for longer distances.

\subsection{Role of near-channel uproots}

When the connection between slope and fluvial system is limited, the most important sources of instream sediment are channel bed and bank undercuts. In such cases root plates which have fallen into a channel and pits which have been created in the direct vicinity of a channel may also be an important source of sediment (Reid 1981; Grizzel and Wolff 1998; Strzyżowski et al. 2016). Many of those pits, however, become overgrown with vegetation in a relatively short period after the windthrow. By comparing our data with data presented by Strzyżowski et al. (2016), who conducted their research in the same catchments 1.5 years after the windthrow in 2013, it can be said that the area of pits adjacent to channels and uncovered with vegetation was 4 times lower during the field survey in 2019.

An additional source of instream sediment in a windthrow area is root plates fallen into a channel. Many of them have already lost all or most of their sediment; therefore, their contribution to increased sediment yield was probably the greatest in the first few years after the windthrow.

\section{Conclusions}

In general, our study suggests that during average hydrometeorological conditions the occurrence of an extensive windthrow within a catchment does not significantly increase the activity of slope and channel processes. In the studied catchments neither pits created by uprooting nor linear surfaces of bare soil created during logging increased erosion intensity or delivered sediment into channels. Regeneration of vegetation within the windthrow was rapid, and in a few years bare soil surfaces had become stabilized. We also did not note increased mass movement activity on windthrowaffected slopes.

The intensity of bedload sediment transport does not appear to be influenced by the presence of the windthrow. No clear and unequivocal pattern of transporting bedload was found when comparing windthrow-affected and control catchments. It may be assumed that local conditions such as minor differences in channel morphology or uneven distribution of rainfall intensity over a given area had greater impact on the intensity of bedload transport than the presence of the windthrow.

One of the most observable changes caused by the windthrow was the delivery of fine sediment into channels by both root plates fallen into a channel and pits created in its neighbourhood. Nevertheless, because most of those root plates were already devoid 
of sediment and pits adjacent to channels were observed to be overgrown by vegetation, it is assumed that the activity of those sources of fine sediment is short-term and diminishes in a few years after a windthrow.

As a result of the windthrow and subsequent forest operations a large amount of differently-sized woody debris was deposited in the channels of the studied catchments. Its influence on channel processes depends on the size of the organic material and way of its deposition in a channel. Fine woody debris, which was often a result of logging operations, may be removed from a channel relatively quickly, especially if the intensity of fluvial processes is high. Larger woody debris may be hung over a channel and fall into it after several decades. Nevertheless, the damming effects created by organic debris after the windthrow influenced the activity of fluvial processes.

\section{Acknowledgements}

This research is part of the project "Impact of extensive windthrow areas on the dynamics of slopefluvial system" funded by the National Science Centre, Poland (DS; grant No. UMO-2017/27/N/ST10/ 00802). Mapping scars created by wood transport in 2016 and recording water levels in 2018 were part of the project "Assessment of large-scale windthrow areas impact on hydrochemical regime and denudation of catchments located in mountain forests (Polish Tatra Mountains)" realized in 2016 (MŻ; grant No. K/KDU/oo0334) and 2018 (MŻ; grant No.

\section{References}

Bac-Moszaszwili M, Burchart J, Głazek J, et al. (1979) Mapa geologiczna Tatr Polskich (Geological map of the Polish Tatra Mountains). Wydawnictwa Geologiczne, Warszawa. (In Polish)

Constantine JA, Pasternack GB, Johnson ML (2005) Logging effects on sediment flux observed in a pollen-based record of overbank deposition in a northern California catchment. Earth Surf Process Landf 30: 813-821. https://doi.org/10.1002/esp.1190

Constantine JA, Schelhaas M-J, Gabet E, et al. (2012) Limits of windthrow-driven hillslope sediment flux due to varying storm frequency and intensity. Geomorphology 175-176: 6673. https://doi.org/10.1016/j.geomorph.2012.06.022

Dąbrowska K, Guzik M (Eds.) (2015) Atlas Tatr: przyroda nieożywiona $=$ Atlas Tatier: neživá príroda $=$ Atlas of the Tatra Mountains: abiotic nature. Zakopane, Tatrzański Park Narodowy. (In Polish)

Douglas I, Spencer T, Greer T, et al. (1992) The impact of selective commercial logging on stream hydrology, chemistry
Sediment accumulation above and erosion below damming sites takes place, which results in creating step-like longitudinal profiles of the channels.

The significant amount of organo-mineral channel steps has reduced the transport of mineral debris in the channels. The period of time during which those steps will affect the channels is related to the durability of woody debris and frequency of extreme hydro-meteorological events capable of destroying those forms. The durability of LWD in the studied area is 30-40 years (Kaczka 2003), and the durability of FWD - less than 10 years. Extreme events in the studied valleys occur on average every 15 years (Gorczyca et al. 2014). Such events will successively clear the channels of organic and mineral debris and in the future they may lead to forming long rocky floor sections which were observed in the studied channels before the windthrow event.

$\mathrm{K} / \mathrm{KDU} / 000494$ ), funded by the forest fund of the State Forests National Forest Holding.

Open Access This article is distributed under the terms of the Creative Commons Attribution 4.0 International License (http://creativecommons. org/licenses/by/4.o/), which permits unrestricted use, distribution, and reproduction in any medium, provided you give appropriate credit to the original author(s) and the source, provide a link to the Creative Commons license, and indicate if changes were made. and sediment loads in the Ulu Segama rain forest, Sabah, Malaysia. Philos Trans Biol Sci 335: 397-406.

https://doi.org/10.1098/rstb.1992.0031

Fischer A, Lindner M, Abs C, et al. (2002) Vegetation dynamics in central european forest ecosystems (near-natural as well as managed) after storm events. Folia Geobotanica 37: 17-32. https://doi.org/10.1007/BFo280318

Fredriksen RL (1970) Erosion and sedimentation following road construction and timber harvest on unstable soils in three small western Oregon watersheds. USDA Forest Serv Res Pap PNW-104, 15 pp.

Gabet EJ, Reichman OJ, Seabloom EW (2003) The effect of bioturbation on soil processes and sediment transport. Annu Rev Earth Planet Sci 31: 249-273.

https://doi.org/10.1146/annurev.earth.31.100901.141314

Gallaway JM, Martin YE, Johnson EA (2009) Sediment transport due to tree root throw: integrating tree population dynamics, wildfire and geomorphic response. Earth Surf 
Process Landf 34: 1255-1269. https://doi.org/10.1002/esp.1813

Gerber W, Rickli Ch, Graf F (2002) Surface erosion in cleared and uncleared mountain windthrow sites. Forest Snow and Landscape Research 77: 109-116.

Gorczyca E, Krzemień K, Wrońska-Wałach D, et al. (2014) Significance of extreme hydro-geomorphological events in the transformation of mountain valleys (Northern Slopes of the Western Tatra Range, Carpathian Mountains, Poland). Catena 121: 127-141.

https://doi.org/10.1016/j.catena.2014.05.004

Grant GE, Wolff AL (1991) Long-term patterns of sediment transport after timber harvest, Western Cascade Mountains, Oregon, USA. In: Sediment and Stream Water Quality in a Changing Environment: Trends and Explanation. IAHS 203.

Gregory KJ, Gurnell AM, Hill CT (1985) The permanence of debris dams related to river channel processes. Hydrol Sci J 30: $371-381$.

https://doi.org/10.1080/02626668509491000

Grizzel JD, Wolff N (1998) Occurrence of windthrow in forest buffer strips and its effect on small streams in northwest Washington. Northwest Science 72: 214-223.

Gurnell AM, Piégay H, Swanson FJ, et al. (2002) Large wood and fluvial processes. Freshw Biol 47: 601-619. https://doi.org/10.1046/j.1365-2427.2002.00916.x

Guthrie RH (2002) The effects of logging on frequency and distribution of landslides in three watersheds on Vancouver Island, British Columbia. Geomorphology 43: 273-292. https://doi.org/10.1016/So169-555X(01)oo138-6

Hancock GR, Evans KG, McDonnell J, et al. (2011) Ecohydrological controls on soil erosion and landscape Evolution. Ecohydrology 5 (4): 478-490. https://doi.org/10.1002/eco.241

Harr RD, Harper WC, Krygier JT, et al. (1975) Changes in storm hydrographs after road building and clear - cutting in the Oregon Coast Range. Wat Resour Res 11: 436-444. https://doi.org/10.1029/WRo11ioo3poo436

Hasiński W (1971) Wpływ wiatrowałów karkonoskich na przebieg denudacji (Impact of windthrows in the Karkonosze Mountains on denudation). Czasopismo Geograficzne 41 (3): 301-303. (In Polish)

Head Office of Geodesy and Cartography (2019a) Digital Elevation Model. http://www.gugik.gov.pl/pzgik/zamowdane/numeryczny-model-terenu (Accessed on 10 January 2018)

Head Office of Geodesy and Cartography (2019b) Orthophotomap.

http://www.gugik.gov.pl/pzgik/zamow-dane/ortofotomapa (Accessed on 14 March 2018)

Hess M (1974) Piętra klimatyczne Tatr (Climatic zones in the Tatra Mountains). Czasopismo Geograficzne 45: 75-93. (In Polish)

Hewlett JD, Helvey JD (1970) Effects of forest clear-felling on the storm hydrograph. Wat Resour Res 6: 768-782. https://doi.org/10.1029/WRoo6ioo3poo768

Imaizumi F, Sidle R, Kamei R (2008) Effects of forest harvesting on the occurrence of landslides and debris flows in steep terrain of central Japan. Earth Surf Process Landf 33: 827-840. https://doi.org/10.1002/esp.1574

Jakob M (2000) The impacts of logging on landslide activity at Clayoquot Sound, British Columbia. Catena 38: 279-300. https://doi.org/10.1016/So341-8162(99)00078-8

Kaczka RJ (2003) The coarse woody debris dams in mountain streams of Central Europe, structure and distribution. Studia Geomorph Carp Balcanica 37: 111-127.

Karwan DL, Gravelle JA, Hubbart JA (2007) Effects of timber harvest on suspended sediment loads in Mica Creek, Idaho. Forest Sci 53: 181-188. https://doi.org/10.1093/forestscience/53.2.181

Keller EA, MacDonald A, Tally T, et al. (1995) Effects of large organic debris on channel morphology and sediment storage in selected tributaries of Redwood Creek, northwestern California. US Geol Surv Prof Paper 1454-P: 1-29.

Kotarba A (1970) The morphogenetic role of foehn wind in the Tatra Mts. Studia Geomorph Carp Balcanica 4: 171-188.

Kotarba A, Kaszowski L, Krzemień K (1987) High-mountain denudation system of the Polish Tatra Mountains. Geographical Studies, Special issue 3: 7-106.

Krzemien K (1992) The high mountain fluvial system the Western Tatra perspective. Geographia Polonica 60: 51-66.

Lewis J, Mori SR, Keppeler ET, et al. (2001) Impacts of logging on storm peak flows, flow volumes and suspended sediment loads in Caspar Creek, California. In: Wigmosta, M.S., Burges, S.J., (Eds.) Land use and watersheds: human influence on hydrology and geomorphology in urban and forest areas. Water Science and Application 2: 85-125. https://doi.org/10.1029/WSoo2poo85

Lyford WH, MacLean DW (1966) Mound and pit microrelief in relation to soil disturbance and tree distribution in New Brunswick, Canada. Harvard Forest Paper 15, pp. 1-18.

McDonald JI (2011) The effects of timber harvesting and windthrow on landslide initiation, southwestern Vancouver Island. M.Sc. thesis, Simon Fraser University, Burnaby, Canada, $172 \mathrm{pp}$.

Megahan WF, King JG, Seyedbagheri KA (1995) Hydrologic and erosional responses of a granitic watershed to helicopter logging and broadcast burning. Forest Sci 41: 777-795.

https://doi.org/10.1093/forestscience/41.4.777

Nakamura F, Swanson FJ (1993) Effects of coarse woody debris on morphology and sediment storage of a mountain stream system in western Oregon. Earth Surf Process Landf 18: 43-61. https://doi.org/10.1002/esp.3290180104

Niedźwiedź T (1992) Climate of the Tatra Mountains. Mt Res Dev 12 (2): 131-146.

https://doi.org/10.2307/3673787

Niedźwiedź T (2003) Częstość występowania mas powietrznych w Polsce południowej w drugiej połowie XX wieku (Frequency of air-masses in southern Poland in the second half of 20th century). Prace Geogr 188: 65-74. (In Polish)

Osterkamp WR, Toy TJ, Lenart MT (2006) Development of partial rock veneers by root throw in a subalpine setting. Earth Surf Process Landf 31: 1-14. https://doi.org/10.1002/esp.1222

Pawlik $€$ (2012) Przekształcenia powierzchni stokowych $w$ Sudetach w wyniku procesu saltacji wykrotowej (Disturbance of hillslope surfaces due to the tree uprooting process in the Sudetes Mts., SW Poland). Landf Anal 20: 79-94. (In Polish)

Pawlik Ł, Migoń P, Owczarek P, et al. (2013) Surface processes and interactions with forest vegetation on a steep mudstone slope, Stołowe Mountains, SW Poland. Catena 109: 203-216. http://dx.doi.org/10.1016/j.catena.2013.03.011

Pawlik Ł, Migoń P, Szymanowski M (2016) Local- and regionalscale biomorphodynamics due to tree uprooting in seminatural and manager montane forest of the Sudetes Mountains, Central Europe. Earth Surf Process Landf 41: $1250-1265$

https://doi.org/10.1002/esp.3950

Phillips JD, Marion DA, Turkington AV (2008) Pedologic and geomorphic impacts of a tornado blowdown event in a mixed pine-hardwood forest. Catena 75: 278-287. https://doi.org/10.1016/j.catena.2008.07.004

Reid LM (1981) Sediment production from gravel-surfaced forest roads, Clearwater basin, Washington. In: Fisheries Research Institute Report. FRI-UW-8108, 247 pp.

Roberts B, Ward B, Rollerson T (2004) A comparison of landslide rates following helicopter and conventional cablebased clear-cut logging operations in the Southwest Coast 
Mountains of British Columbia. Geomorphology 61: 337-346. https://doi.org/10.1016/j.geomorph.2004.01.007

Roering JJ, Schmidt KM, Stock JD, et al. (2003) Shallow landsliding, root reinforcement, and the spatial distribution of trees in the Oregon Coast Range. Can Geotech J 40: 237-253. https://doi.org/10.1139/to2-113

Skiba S (2002) Mapa gleb Tatrzańskiego Parku Narodowego (Soil map of the Tatra National Park). In: Borowiec, W., Kotarba, A., Kownacki, et al. (Eds.), Przemiany środowiska przyrodniczego Tatr. TPN-PTPNoZ, Kraków-Zakopane. pp 21-26. (In Polish)

Small TW, Schaetzl RJ, Brixie JM (1990) Redistribution and mixing of soil gravels by tree uprooting. Prof Geogr 42: 445457.

https://doi.org/10.1111/j.0033-0124.1990.00445.x

Strzyżowski D, Fidelus J, Żelazny M (2016) Geomorphological changes within a hillslope caused by a windthrow event in the Tatra Mountains, Southern Poland. Geogr Ann Ser A Phys Geogr 98: 347-36o.

http://dx.doi.org/10.1111/geoa.12141

Strzyżowski D, Fidelus-Orzechowska J, Żelazny M (2018) Sediment transport by uprooting in the forested part of the Tatra Mountains, southern Poland. Catena 160: 329-338. https://doi.org/10.1016/j.catena.2017.09.019

Swanson FJ, Dyrness CT (1975) Impact of clear-cutting and road construction on soil erosion by landslides in the western Cascade Range, Oregon. Geology 3: 393-396.

https://doi.org/10.1130/oo91-

7613(1975)3<393:IOCARC>2.o.CO;2
Thévenet A, Citterio A, Piégay H (1998) A new methodology for the assessment of large woody debris accumulations on highly modified rivers (example of two French piedmont rivers). Regulated Rivers: Research \& Management: An International Journal Devoted to River Research and Management 14(6): 467-483.

Wallace JB, Webster JR, Eggert SL, et al. (2001) Large woody debris in a headwater stream: long - term legacies of forest disturbance. Int Rev Hydrobiol 86(4 - 5): 501-513. https://doi.org/10.1002/15222632(200107)86:4/5<501::AID-IROH5O1>3.0.CO;2-8

Wohlgemuth T, Kull P, Wüthrich H (2002) Disturbance of microsites and early tree regeneration after windthrow in Swiss mountain forests due to the winter storm Vivian 1990. For Snow Landsc Res 77: 17-47.

Wohlgemuth T, Schwitter R, Bebi P, et al. (2017) Postwindthrow management in protection forests of the Swiss Alps. Eur J Forest Res 136: 1029-1040. https://doi.org/10.1007/s10342-017-1031-x

Wright KA, Sendek KH, Rice RM, et al. (1990) Logging effects on streamflow: storm runoff at Caspar Creek in northwestern California. Wat Resour Res 26: 1657-1667. https://doi.org/10.1029/WR026ioo7p01657

Ziemer RR (1981) The role of vegetation in the stability of forested slopes. Proceedings of the International Union of Forestry Research Organizations. XVII World Congress, 6-17 September 1981, Kyoto, Japan, vol. I. pp 297-308. 